Sains Malaysiana 50(1)(2021): 207-226

http://dx.doi.org/10.17576/jsm-2021-5001-21

\title{
Annexin A1 (ANXA1): A Systematic Review of Its Role in Inflammation
}

(Aneksin A1 (ANXA1): Suatu Ulasan Sistematik tentang Peranannya dalam Keradangan)

\author{
SANGgaVi NADARAJAN, NORAZRINA AZMi, MALINA JASAMAI \& ENDANG KUMOLOSASI*
}

\begin{abstract}
Inflammation is a body response towards any injury or tissue damage. It involves the accumulation of neutrophils and release of inflammatory mediators. ANXA1, a $37 \mathrm{kDa}$ glucocorticoid inducible protein plays an important role in resolving inflammation. The unique $N$-terminal and its mimetic peptide exert strong anti-inflammatory actions. This study was conducted to review the roles of ANXA1 in inflammation and identify any other reported roles. Electronic search was done whereby a total of 3797 articles were located from three databases, namely Ovid MEDLINE, Science Direct, and PubMed. Articles on ANXA1 and inflammation were selected based on inclusive criteria and review papers were excluded. Bias analysis was performed based on bias risk tool and 27 articles were included in the study. It was found that ANXA1 was able to resolve inflammation in many inflammatory diseases. Upon treatment with glucocorticoid, ANXA1 is induced and its significant expressions in tissues are important in resolving inflammation. However, this effect can be reversed by administering an anti-annexin antibody. This protein also acts on members of all formyl peptide receptors (FPR) and activates them to initiate reaction. It acts mainly by causing the death of neutrophils through apoptosis. In addition, ANXA1 is identified as a marker in cancer cells which determines the survival rates. In conclusion, ANXA1 is a key modulator in resolving inflammation in many diseases and is actively being induced upon glucocorticoid treatment.
\end{abstract}

Keywords: Annexin A1; Annexin 1; ANXA1; inflammation; Lipocortin-1; phospholipase A2 inhibitory protein

\section{ABSTRAK}

Keradangan adalah tindak balas badan terhadap sebarang kecederaan atau kerosakan tisu. Ia melibatkan pengumpulan neutrofil dan pembebasan perantara keradangan. ANXA1, sejenis protein yang boleh diaruh glukokortikoid 37 $k D a$ memainkan peranan penting dalam menangani keradangan. Terminal- $N$ yang unik dan peptida mimetiknya menunjukkan tindakan anti-keradangan yang kuat. Kajian ini dijalankan untuk mengkaji peranan ANXA1 dalam keradangan dan mengenal pasti lain-lain peranan yang dilaporkan. Pencarian elektronik dilakukan dan sejumlah 3797 artikel diperoleh daripada tiga pangkalan data iaitu Ovid MEDLINE. Science Direct dan PubMed. Artikel mengenai ANXA1 dan keradangan dipilih berdasarkan kriteria inklusif dan tidak termasuk artikel ulasan. Analisis pincang dilakukan berdasarkan peralatan risiko pincang dan 27 artikel dimasukkan dalam kajian. Didapati bahawa ANXA1 dapat menangani keradangan dalam pelbagai penyakit radang. Semasa rawatan menggunakan glukokortikoid, ANXA1 diaruh dan ekspresi ketaranya dalam tisu adalah penting dalam menangani keradangan. Walau bagaimanapun, kesan ini dapat dibalikkan dengan menggunakan antibodi anti-aneksin. Protein ini juga didapati bertindak pada semua jenis reseptor peptida formil (FPR) dan mengaktifkannya untuk memulakan tindak balas. Ia bertindak terutamanya dengan menyebabkan kematian neutrofil melalui apoptosis. Sebagai tambahan, ANXA1 dikenal pasti sebagai penanda sel barah yang menentukan kadar kemandirian. Kesimpulannya, ANXA1 adalah modulator utama dalam menangani keradangan dalam pelbagai penyakit dan secara aktif diaruh oleh rawatan glukokortikoid.

Kata kunci: Aneksin A1; Aneksin 1; ANXA1; keradangan; Lipokortin-1; protein penyekat fosfolipase A2

\section{INTRODUCTION}

Inflammation is a process which reacts upon any damage or injury to tissues (Soehnlein \& Lindbom 2010). Redness, swelling, pain, heat, and loss of function often denote inflammation. The process of inflammation involves a few important events, such as vasodilatation, vascular leakage and expression of inflammatory mediators. Then, all these events will cause the build-up of neutrophils, macrophages and other inflammatory cells which migrate to the site of injury or infection. In inflammatory process, vascular endothelium plays a vital role as it releases eicosanoids and cytokines. These molecules are known to cause inflammation (Ricciotti \& Fitzgerald 2011). 
The function of vascular endothelium is to engage leukocytes via the presence of adherent molecule to the site of injury (Cronstein \& Weissmann 1993). Inflammation causes the emergence of a scar (Ker et al. 2000). Resolution of inflammation is important in regulating our body balance (Ortega-Gómez et al. 2013). Death of neutrophil is an important event towards resolution of inflammation and it is engulfed by macrophages (Fox et al. 2010). The removal of neutrophil shifts the situation to anti-inflammatory condition (Fadok et al. 1998). At the final stage for neutrophil to undergo apoptosis, it releases mediators to block the neutrophil engagement during the inflammatory process (Ortega-Gómez et al. 2013).

One of the proteins released during inflammation is ANXA1 (Ortega-Gómez et al. 2013). ANXA1 or better known as lipocortin-1 (37 kDa) is a glucocorticoid inducible protein that plays certain biological functions (Gerke et al. 2005). It is mostly found in neutrophils, eosinophils, macrophages, mast cells and myeloid lineage (Lima et al. 2017). Anti-inflammatory actions are actually demonstrated by its unique $\mathrm{N}$-terminal peptide. Peptide derived from ANXA1, which is Ac2-26, is able to mimic the action (Vong et al. 2007).

These effects are regulated upon its interaction via GPCR: FPR Type 2/lipoxin $\mathrm{A}_{4}$ receptor (ALX). Moreover, it has different functions, such as cell proliferation, differentiation and membrane trafficking (Gerke et al. 2005). Its anti- inflammatory effects are seen through the blocking of the leukocyte movement, PLA, COX-2, and iNOS expression. It also stimulates the release of IL-10 and is involved in neutrophil apoptosis (Lima et al. 2017). This protein is secreted whenever stress-induced inflammation takes place by rising the cortisol production (Probst-Cousin et al. 2002).

Several conducted studies showed that lack of ANXA1 could lead to etiology of inflammatory disease (Kosicka et al. 2013). This systematic review is mainly conducted to review the relation between ANXA1 and inflammation, especially its role in inflammatory diseases and determine its role in inflammatory process.

\section{MATERIALS AND METHODS}

\section{SEARCH STRATEGY}

This study was mainly conducted to review studies of ANXA1 in inflammation. Information for this study was assembled by using electronic bibliographic databases, such as Ovid MEDLINE, PubMed, and Science Direct (Lopresti 2017). To search for these articles, relevant subject headings and keywords were used, such as inflammation, redness, pain, swelling, annexin A1, ANXA1, lipocortin-1, annexin 1, and phospholipase $\mathrm{A}_{2}$ inhibitory protein. Synonyms of the word 'inflammation' and 'annexin A1' were also used to extend the search. Upon increasing the sensitivity of search, Boolean operator 'AND' was used to combine the keywords (Hatah et al. 2014). Examples of search terms used were 'inflammation OR redness OR pain OR swelling' AND 'annexin A1 OR ANXA1 OR lipocortin-1 OR annexin 1 OR phospholipase $\mathrm{A}_{2}$ inhibitory protein'.

\section{INCLUSIVE AND EXCLUSIVE CRITERIA}

Inclusive criteria: To select relevant articles, they were required to be in full report, which could be from all types of study design with a control or comparison group. To be accepted, the study in articles may involve annexin A1 and inflammation, as well as written in English. Exclusive criteria: Articles were excluded from this study if they were conference report, manual, patent, bibliography, review articles, symposium, book, bibliometric study, index, editorial or survey. Articles were also excluded if they were written in non-English. Then, the articles were imported into Reference Manager, and EndNote. Meanwhile, duplicates were removed (Aziz et al. 2016). Articles were also excluded if the abstract or journal was unattainable. Additional relevant studies were conducted by assessing the reference lists of included literature. These additional references were then compared with the original search results while duplicates were removed (OHAT 2015).

\section{STUDY SELECTION}

Based on the inclusive and exclusive criteria, the retrieved articles were screened. Articles which describe a clear methods, results and outcome were included for analysis (Aziz et al. 2016). Titles or abstracts were screened. Articles that were not relevant to the research title were excluded. Next, full text articles were retrieved to select articles which have met the inclusion criteria. The final decision on article selection will depend on the full text (OHAT 2015).

\section{DATA EXTRACTION AND ANALYSIS}

Data were extracted to evaluate the role of ANXA1 in inflammation by using data extracted from the Office of Health Assessment and Translation for conducting the systematic review, including evidence integration (OHAT 2015) which consisted of study design, experimental model, methods and results. Data were divided into in vitro and in vivo studies. Data were analysed by using a narrative review. The study analysis was focused more on the results obtained from the experiments in each study. The first author, year, animal models and treatment/ compounds (in vivo studies), cell/ tissue model/cell type (in vitro studies), methods, results and comments were 
included and a summary of the findings is shown in Tables 1 and 2 (supplemental data).

\section{BIAS ANALYSIS}

Bias was analysed by using the bias risk tool provided by the Office of Health Assessment and Translation (OHAT) bias risk tool handbook. The potential bias of study was evaluated.

\section{RESULTS AND DISCUSSION}

\section{SEARCH RESULTS}

A total of 3797 articles were imported into the Endnote from three different databases. Taking into consideration the inclusion and exclusion criteria, a total of 27 articles were included in the final analysis (Figure 1). A summary of the findings is included in Tables 1 and 2 (Supplemental data).

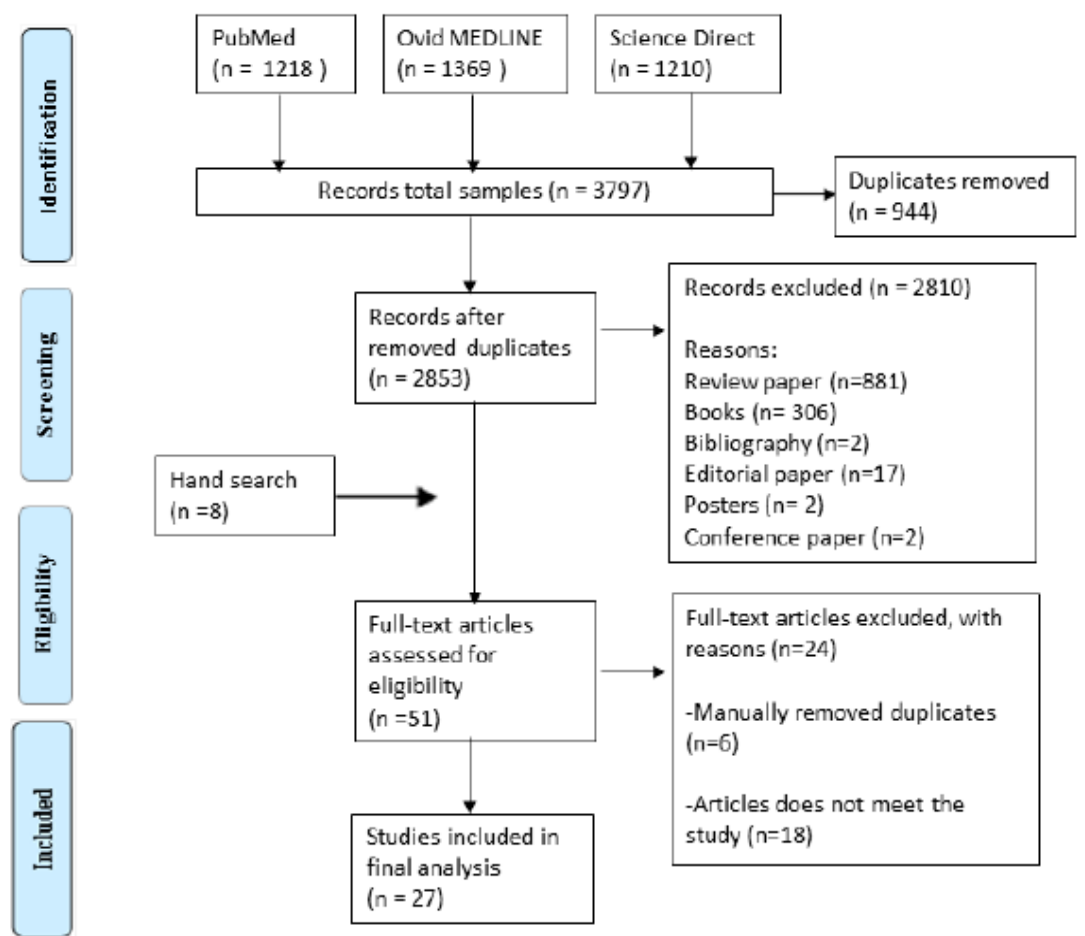

FIGURE 1. Flow diagram on inclusion and exclusion of systematic review

\section{ANXA1 IN INFLAMMATORY DISEASES}

In autoimmune diseases, ANXA1 was found to restrict TH17 cells and attenuated the severity. Complete Freund's adjuvant (CFA) and human recombinant protein ANXA1 were administered into the ANXA1 deficient and wild type (WT) mice. Control mice were left untreated. The expression of annexin protein was detected by using western blot technique. Mice which did not have ANXA1 exhibited severe inflammation, which was significantly different $(p<0.05)$ from the WT mice. Enhanced level of monocytes, neutrophils, macrophages and Th17- $\mathrm{CD} 4^{+} \mathrm{T}$ cells were observed in ANXA1 deficient mice. Absence of this protein lead to T-cell proliferation and expression of ANXA1 diminished the pro-inflammatory cytokines and autoimmune retinal inflammatory disease. Lack of ANXA1 expression showed an increase in inflammation severity.

This was because proliferation and activation of TH17 cells took place uncontrollably. These events occurred due to the small capability to introduce SOCS3, which gave an unrestrained phosphorylation 
of STAT3 pathway. CD4+ cells isolated from tissues that lack ANXA1 demonstrated a greater level of TH17 cells. Therefore, the delivery of human recombinant ANXA1 restricts CD4+ cell proliferation and lowers proinflammatory cytokines, such as IL-17, IFN- $\gamma$, IL-6, which reduces the severity of inflammation. Therefore, it showed that this protein had actively regulated the TH17 cells (Yazid et al. 2015).

In addition, another study was conducted to evaluate the beneficial effect of ANXA1 in experimental allergic conjunctivitis (AC). The experiment was carried out by giving ovalbumin injection to cause AC by using WT and ANXA1 knockout mice. Both types of mice were then treated with mimetic peptide Ac-26 and dexamethasone. Negative control mice from both groups were treated with normal saline. The $\mathrm{p}$ value of test groups indicated a statistically significantly different $(\mathrm{p}<0.05)$ as compared to the negative control group. Therapy by using ANXA1 mimetic peptide and dexamethasone had markedly lowered the clinical appearance of AC, IgE, leukocyte and mast cell degranulation in conjunctiva of ANXA1 knockout mice as compared to WT mice. Therefore, the effect of dexamethasone was associated with enhancement of ANXA1 expression in ocular tissue (Gimenes et al. 2015). The study of Rodrigo et al. (2004) demonstrated the expression of ANXA1 in normal and chronically inflamed nasal mucosa. Samples were obtained from healthy subjects, patients with perennial rhinitis and nasal polyps. This protein was found to be expressed highly in ciliated cells. However, the study had shown that there was no difference in expression between healthy and normal cel.

Another study was conducted on ANXA1 deficient and WT mice to determine the airway hyper-responsiveness in mouse model of asthma. Mice and control mice were given ovalbumin and normal saline, respectively. The lung compliance and airway resistant were determined in both types of mice. The level of $\operatorname{IgE}, \operatorname{IgG} 2 \mathrm{a}$, and $\operatorname{IgG} 2 \mathrm{~b}$ were high in ANXA1 deficient mice and they were more sensitive towards airway responsiveness as compared to WT mice. This suggested that ANXA1 played a critical role in asthma as the absence of ANXA1 caused a rise in antibody response (IgE, IgG2a, IgG2b) and hypersensitivity in asthma ( $\mathrm{Ng}$ et al. 2011).

Similar expression of ANXA1 was seen in ulcerative colitis (UC) patients when tissue samples from mild, moderate, severe UC of inflammed colons, and severe UC from noninflamed colons were collected. Before tissue samples were taken, patients were given amino salicylate (ASA) and oral prednisolone. Healthy patients without UC served as control. The release of ANXA1 was detected in inflamed severe UC patients but not detected in slight or moderate UC. Myeloperoxydase (MPO) activity was used to evaluate the extent of tissue granulocyte infiltration.
Therefore, the MPO activity in healthy colons was not statistically significantly different with $\mathrm{p}=0.606$, while $\mathrm{p}=0.036$ for the inflamed colons as compared to the control subjects (Vergnolle et al. 2004). A study on gastric mucosal lesion by Martin et al. (2008) showed similar results, in which this protein had a vital role in regulating the damage. The role of ANXA1 was tested in ANXA1 deficient and wild type mice. After the induction of ulcer, mice were given ANXA1 mimetic peptide, Ac2-26 and dexamethasone. Healthy mice were kept as control subjects. Western blot was used to examine the presence of this protein during the curing of injury process. ANXA1 expression was strongly increased in ulcerated gastric tissue and administration of an ANXA1 mimetic peptide improved ulcer healing, whereas an antagonist of the main receptor for ANXA1 impaired healing. The ANXA1-deficient mice showed similar susceptibility to indomethacin-induced gastric damage. However, the healing of that damage was significantly impaired in the ANXA1-deficient mice as compared to the wild-type mice. The expression of ANXA1 was significantly different from healthy controls, $p<0.05$ (only found intact ANXA1, 37 $\mathrm{kDa}$ in the healthy mice, but in the ulcer cleavage product of ANXA1 $33 \mathrm{kDa}$ ) was also found. Furthermore, ANXA1 was highly expressed in gastric mucosal lesion. Alleviation of gastric wound was achieved by administering ANXA1 mimetic peptide, Ac2-26. Since ANXA1 binds and activates FPR; hence, antagonist of FPR will reverse the process of healing. Boc2, the FPRL-1 as an antagonist of FPR also showed the corresponding outcome, whereby they impaired the healing. Not only this protein (ANXA1), but lipoxin A4 also promotes the reduction of inflammation (Martin et al. 2008). Taken together, these data support the hypothesis that ANXA1 makes an important contribution to the healing of gastric mucosal damage.

Investigation on the reduction of plasma ANXA1 was done in obese population. ANXA1 level was assessed in human plasma obtained from overweight and obese patients, whereas the normal subjects served as a control. There was an opposite correlation with $\mathrm{p}<0.001$ between plasma ANXA1 protein and body mass index (BMI), as well as to that of waist to hip ratio (WHR). As the fat rises, the ANXA1 concentration decreases. Low level of ANXA1 was observed in high WHR. There was no relation between ANXA1 to blood glucose and age (Kosicka et al. 2013).

Another study was conducted on multiple sclerosis patients, whereby their tissues and those without any neurological diseases were collected to investigate the expression of ANXA1. Control cells were left untreated and ANXA1 was found to be expressed in multiple sclerosis lesion with reduction in concentration from active lesions to chronic levels. Multiple sclerosis (MS) patients had ANXA1 expression detected in the plaques which were in 
macrophages and reactive astrocytes. ANXA1 abolishes the activation of T-cell lines. Increase in ANXA1 expression in active astrocytes leads to differentiation and activation of astrocytes. The additional presence of ANXA1 gives impact to lymphocytes and macrophages to reduce inflammation. In CNS patients of MS, the treatment upon glucocorticoids causes the induction of ANXA1 which contributes in decreasing the symptoms of inflammation (Probst-Cousin et al. 2002).

Reduction of ANXA1 concentration in human urothelium (UE) and cell line TEU-2 reduced the cell survival upon subjection to bacterial toxin. In the same study, cells were obtained from patients with no symptom and from bladder pain syndrome (BPS) patients. The distribution of ANXA1 was mainly on cytoplasm and mRNA gene expression was reduced in BPS patients as compared to control patients (no symptom) subjects ( $\mathrm{p}$ $<0.05$ ). This study showed that there was a decrease in cell survival in absence of ANXA1 (Monastyrskaya et al. 2013).

\section{THE DISTRIBUTION AND LOCALISATION PATTERN OF} ANXA1

Complete Freund's adjuvant (CFA) administration caused chronic inflammation in mice. Tissue samples were obtained from healthy and inflammatory mice. It was then used for ANXA1 and mRNA gene detection. The result showed that two different bands of ANXA1 were formed, which are the active form $37 \mathrm{kDa}$ and inactive form 33 $\mathrm{kDa}$. ANXA1 was detected in neutrophils, macrophages, eosinophils, and fibroblasts. The level of ANXA1 was high after CFA injection and significantly different from untreated mice $(\mathrm{p}<0.01)$. The distribution pattern was mainly observed in cytoplasm and cell surface (Gibbs et al. 2002). Administration of carrageenin had increased ANXA1 level in cytoplasm and administration of antiANXA1 antibody detected ANXA1 in nucleus and cytosol. There was a distribution of ANXA1 in matrix and granules of the cytosol (Oliani et al. 2002).

\section{ANNEXIN A1 CAUSES THE LEUKOCYTE EMIGRATION AND NEUTROPHIL DETACHMENT}

Human leukocyte elastase (HLE) caused the cleavage of ANXA1 brimful length of $37 \mathrm{kDa}$ protein into smaller part, which is inactive $33 \mathrm{kDa}$ protein. Upon endothelial fixing, ANXA1 was detached from the leukocyte and cleaved. Administration of ANXA1 to leukocytes caused the shortening of ANXA1, which was influenced by the HLE activity. The sustained ANXA1 at the leukocyte has a role in controlling leukocyte emigration via its $\mathrm{N}$-terminal peptide into the damaged tissue at the inflammatory place (Rescher et al. 2006).
ANXA1 and its mimetic peptide are thought to cause neutrophil detachment to control inflammatory process. This was proven by conducting an experiment on mice, whereby zymosan was injected and neutrophil adherent to post capillary venule was assessed. ANXA1 and its mimetic peptide were then injected into the mice. Control animals were treated with normal saline. Delivery of zymosan caused a rise in cell adhesion and emigration, but once ANXA1 and mimetic peptide were given, it caused a drastic detachment of neutrophil. The leukocytes were separated and returned to the bloodstream. This result was significantly different from the control group $(\mathrm{p}<0.05)$ (Lim et al. 1998).

ANXA1 blocks leukocyte movement through reduction of neutrophils and monocytes adhesion to vascular endothelium (Ferlazzo et al. 2003), thus, causes the death of neutrophils (Monastyrskaya et al. 2013). In inflammatory condition, neutrophils permeate to sites of inflammation (Rodrigo et al. 2004) and this permeation is determined by the expression of ANXA1 (Gibbs et al. 2002). The amount of neutrophils increased upon inflammation, whereby ANXA1 controlled their accumulation (Gibbs et al. 2002). Administration of ANXA1 mimetic peptide blocks the engagement of neutrophils in acute and chronic inflammation. ANXA1 lowers neutrophil adhesion and migration, and thus develops the separation of neutrophils adherent to post capillary venules to regulate inflammation (Lim et al. 1998).

\section{STIMULATION OF IL-10, BLOCKS THE NITRIC OXIDE SYNTHESIS}

Murine macrophages cell line J774 were collected and cultured. The release of nitric oxide (NO) was determined. The cells were then induced with LPS and the control cells were without induction. Then, RNA was isolated from treated and control cells. It was found that LPS caused the release of IL-10 (anti-inflammatory cytokine). ANXA1 peptide was also able to induce IL-10 and block the NO liberation. Peptide Ac2-26 as mimic of ANXA1 was able to block nitric oxide synthase (iNOS) and its mRNA gene accumulation. Therefore, role of ANXA1 as an anti-inflammatory mediator has caused the induction of IL-10, which then blocked the nitric oxide synthesis (Ferlazzo et al. 2003). NO was produced due to inflammation and from the role of iNOS in cells such as macrophages, synovial fibroblast, osteoblasts, and chondrocytes. The release of NO was mediated by pro-inflammatory cytokines. ANXA1 acted in this situation by moving to the cell surface upon treatment of dexamethasone. One of the actions of ANXA1 is that it blocked the NO after it was inducted by glucocorticoids (Yang et al. 1998). Dexamethasone was able also to 
inhibit hyperalgesic effect produced by PGE2, carrageenin, bradykinin, TNF- $\alpha$, IL- 6 , IL-8 and dopamine (Ferreira et al. 1997). ANXA1 was able to inhibit the hyperalgesic effect by blocking the cytokines and the COX-2 which produced prostaglandin. However, the addition of antiANXA1 antibody reversed the inhibitory action (Ferreira et al. 1997). Ac2-26 was able to regulate neutrophilic inflammation by stimulating route of Bax, casapase 3 and blocking the survival pathways, such as Mcl-1, extracellular signal-regulated Kinase-1 (ERK1/2) and NF- $\kappa \beta$ (Vago et al. 2012).

\section{ANXA 1 AND FORMYL PEPTIDE RECEPTOR}

Peripheral blood granulocytes, monocytes, and HEK 293 cells express formyl peptide receptor (FPR), formyl peptide receptor like-1 (FRP 1), and formyl peptide receptor like 2 (FPR 2) were used. Proteolytic enzymes cleavage the N-terminal domain of ANXA1 produced Ac1-25 peptide. This peptide changed the neutrophil morphology and ANXA1 was able to activate all FPR family at the monocytes and granulocytes. However, it was clear that the activation of FPRs had more complex consequences and could also promote the resolution of inflammation. It was found that one of the antiinflammatory actions of this protein was due to activation of FPR (Ernst et al. 2004). Moreover, this protein also exerted its anti-nociceptive effects via FPR. When mice were induced with CFA to cause inflammation, BML-111, Boc-1 and Anxa $1_{2-26}$ were injected. Control mice group was left untreated. The administration of CFA caused increase in ANXA1 significantly with $p<0.01$ as compared to control mice. BML-111 and Anxa $1_{2-26}$ decreased the mechanical nociception, whereas Boc-1 reversed the action (Pei et al. 2011).

\section{ROLE OF ANXA1 IN INFLAMMATION VIA INHIBITION OF INFLAMMATORY MEDIATORS}

Arachidonic acid is synthesised from linoleic acid and produces PLA2. This acid functions as a substrate for a few vital enzymes, in which some of them are cyclooxygenase to produce prostaglandin and lipooxygenase for formation of hydroperoxyicosatetranoic acid. These enzymes are found to be responsible for inflammation. Therefore, ANXA1 acts to inhibit these enzymes in order to resolve inflammation (Hirata et al. 1980). It also blocks the eicosanoid mediators, interrupts leukocyte diapedesis by attaching to specific surface receptors of granulocytes and macrophages (Flower \& Rothwell 1994). ANXA1 can block the COX-2 through administration of dexamethasone and stops the release of prostaglandin. This eventually leads to inhibition of hyperalgesic effects (Ferreira et al. 1997). In non-small cell lung cancer cells, the expression of COX-2 is high, thus, promotes to inflammatory status. Green tea extract (GTE) is found to stimulate the release of ANXA1 in cancer cells so as to help reduce inflammation by inhibiting COX2. Therefore, stopping further release of PGE2 (Lu et al. 2012). IL-1 $\beta$ has enhanced the presence of COX-2. GTE can block COX-2 and PLA2 via stimulation of ANXA1. GTE influences in a few inflammatory routes through regulation of NF- $\kappa \beta$, epidermal growth factor receptor (EGFR) or human epidermal growth factor receptor 2 (HER2) and mitogen-activated protein kinase (MAPK) (Adhami et al. 2007).

\section{ANXA1 AS A MEDIATOR OF GLUCOCORTICOID ACTION}

A study by Hirata et al. (1980) used rabbit peritoneal neutrophils treated with glucocorticoids. Control cells were left untreated. This study was conducted to determine the inhibition of PLA 2 pathway, upon release by arachidonic acid and inhibited by PLA 2 inhibitory protein. It provided evidence that when glucocorticoids were given, it stimulated the release of ANXA1, which then lowered the synthesis of prostaglandins by blocking $\mathrm{PLA}_{2}$ pathway. Percentage of inhibition varied, depending on the strength of glucocorticoids used. Flucinolone acetonide had the highest inhibition and this action was regulated by glucocorticoid receptors. To determine this protein's action on glucocorticoid receptor, LPS induced mice were treated with dexamethasone and rolipram. Peptide Ac2-26 was given as mimic peptide of the ANXA1 action. Administration of rolipram and dexamethasone lowered the number of neutrophils and enhanced cell death. The level of ANXA1 was significantly high $(\mathrm{p}<0.01)$ as compared to the control mice. There was a correlation between intact ANXA1 and proapoptotic events. Stimulation effect of Ac2-26 due to glucocorticoid treatment helped to resolve inflammation by providing neutrophil cell death (Vago et al. 2012). A similar study showed that upon administration of dexamethasone, ANXA1 was induced. When rats were given $\mathrm{PGE}_{2}$, carrageenin, bradykinin, and dopamine, it evoked hyperalgesic actions. However, this action was blocked significantly by the administration of ANXA1 as compared to untreated rats. Therefore, it indicated that the anti-hyperalgesic actions of dexamethasone was perform through ANXA1 role (Ferreira et al. 1997).

Synovial tissues of adjuvant arthritis (AA) induced rats were removed and treated with LPS and dexamethasone. Control rats were treated with purified mouse IgG. Due to the presence of glucocorticoid, ANXA1 was induced and found to be expressed in synovial macrophages in a high number. Dexamethasone inhibited significantly $(\mathrm{p}<0.001)$ with NO production from control rat. A study by Yang et al. (1998) also supported the role of ANXA1 in blocking NO production upon 
glucocorticoid treatment. When topical glucocorticoid was given, the same result indicated that it was induced by ANXA1. Rats treated with betamethasone-17-valerate and control rats with vehicle and the presence of ANXA1 was detected. This glucocorticoid inhibited oedema formation at $55 \%$ with p-value of $<0.01$ as compared to vehicle control. Glucocorticoids interrupt inflammation and act as immunosuppressants. They are used to treat inflammatory diseases, mainly autoimmune disorders. However, its mechanism is not fully understood but is found to depends on regulatory proteins (Vago et al. 2012). Induction of this protein (ANXA1) by glucocorticoid is controlled through the cytoplasmic glucocorticoid receptors but can decline via the addition of antagonist such as progesterone (Hirata et al. 1980). ANXA1 was also induced during the administration of glucocorticoids in inflammatory arthritis. Mice which received arthritogenic $\mathrm{K} / \mathrm{BxN}$ as an arthritis model were given dexamethasone to treat inflammation and control mice were left untreated. The tissue from mice was taken for analysing the ANXA1 concentration. Results showed that the presence of dexamethasone increased ANXA1 significantly with $\mathrm{p}<0.05$ as compared to controlled mice. Therefore, ANXA1 acts as an indicator to determine the effectiveness of dexamethasone in inflammatory arthritis (Patel et al. 2012). Glucocorticoids block the phospholipase A2 in affecting the conversion of arachidonic acid to prostaglandin. ANXA1 is also inhibitor for PLA2 and its synthesis is induced by glucocorticoid. This study proposed that ANXA1 inhibits the chemotaxis of neutrophils by blocking the phospholipase A2. Through this, it regulates the lymphocyte mitogenesis, release of histamine from mast cell, chemotaxis of leukocyte, function of bradykinin on fibroblast and desensitisation of $\beta$-adrenergic receptors on C6 astrocytoma cells (Hirata et al. 1980). Therefore, from these studies it can be concluded that the antiinflammatory effect was produced via induction of ANXA1 by glucocorticoid (Ahluwalia et al. 1995).

\section{ANXA1 ACTING AS A STRESS PROTEIN}

To determine whether ANXA1 is a stress protein, A549 and HeLa cells were treated with heat, hydrogen peroxide $\left(\mathrm{H}_{2} \mathrm{O}_{2}\right)$ and sodium arsenite and control cells were left untreated. Upon heat, $\mathrm{H}_{2} \mathrm{O}_{2}$ and sodium arsenite treatment, ANXA1 and Mrna gene were stimulated, released and the level increased in both cell types. Besides, this protein was dispersed from cytoplasm to nucleus in untreated cells, whereas to nucleus and perinuclear region in treated cells. This movement indicated that it is present in nucleus once the treated cells were under stress condition. Its role in resolving stress induced transcriptional activation was investigated and the alteration was significantly different from untreated cells $(\mathrm{p}<0.05)$ (Rhee et al. 2000).

\section{EXPRESSION OF ANXA1 IN CANCER CELL PROGRESSION}

A study conducted on isolation of phospholipase A2 (PLA2) inhibitory protein (ANXA1) which is a prognostic influence on oral squamous cell carcinoma. An immunohistochemical procedure was carried out to determine the expression of ANXA1 as a marker in predicting the prognosis of oral cancer. Experiment was conducted by using specimens from healthy patients as control, oral epithelial dysplasia (OED) and oral squamous cell carcinoma (OSCC). In normal oral epithelia (NOE), this protein was found significant in plasma membrane but reduced in OED and OSCC (Lin et al. 2008). Its presence of ANXA1 in nucleus was significant for OED and OSCC. Enhancement in ANXA1 expression linked with bigger tumour size and distant metastasis. ANXA1 nuclear pigmentation in tumour and distant metastasis had the poorest survival rates. The lowering of ANXA1 in membranous pigmentation in OSCC was not significantly linked to patient's overall survival rate. ANXA1 nuclear positive tumours had lower survival rates than that of nuclear negative tumours. It showed that ANXA1 nuclear staining predicted a poor overall survival. In cancer cells, ANXA1 is mainly localised in nuclear and directly participates in tumour invasion. The nuclear translocation took part in controlling cell proliferation. Therefore, this protein is an important marker to speculate the prognosis of oral cancer (Lin et al. 2008).

In another study, they ruled out to investigate the effects of ANXA1 mimetic peptide in cervical cancer. $\mathrm{SiHa}$ cells obtained from cervix were treated with ANXA1 mimetic Ac2-26. Control cells were left untreated. From this study, the cell proliferation, gene expression and morphology were identified. Upon treatment with Ac226 , there were no morphological changes. This mimetic peptide has shown to reduce cell proliferation of cancer cells as compared to the untreated group with $\mathrm{p}<0.05$. Five genes, which were TPT1, LDHA, NCOA3, HIF1A, and RAB13, were upregulated and one was down regulated which is the ID1 gene (Prates et al. 2015). From this study, ANXA1 may regulate ID1 gene by decreasing its expression and may be used as a possible therapeutic target. ID1 belongs to a family of small molecules of short length (13 to $20 \mathrm{kDa}$ ) and acts as an inhibitor of differentiation or DNA binding and it also regulates the effects of transcription factors on targeted genes. This gene was over expressed in cervical cancer but after treatment with peptide, it was reduced. Over expression lead to antagonistic of tumour cells and became independent marker for this tumour. When ANXA1 was present at low level in cervical cancer, it could be used as a marker in tumour progression. From this study, the involvement of ANXA1, Ac2-26 in the altered expression of genes involved in tumorigenic processes, which could potentially be applied as a therapeutic indicator of cervical cancer (Prates et al. 2015). 
Studies on impact of green tea in inducing ANXA1 have shown to block the COX pathway in non-small cell lung cancer cells (NSCLCC). Cells of A549, H157, and H460 of lung cancer were treated with green tea extract (GTE) and control group was left untreated. Green tea has enhanced the level of ANXA1 protein and ANXA1 mRNA expression in $\mathrm{H} 157$ and $\mathrm{H} 460$ cells. Induction of ANXA1 by GTE caused the blockage of COX-2 expression in all three cells. However, the presence of $1 \mathrm{~L}-1$ beta has caused reduction in GTE induced ANXA1. Rise in the level of ANXA1 has caused reduction in the COX-2 and PLA2 in A549 and H460 cells. Up regulation of COX-2 has led to enhance production of prostaglandin. This in turn caused an increase in cell proliferation. Blocking COX 2 and PLA2 activity of ANXA1 has been influenced by types of cell used. GTE is efficacious in inducing ANXA1; hence, inhibiting COX-2 in non-small cell lung cancer cells (NSCLCC) (Lu et al. 2012). Gao et al. (2014) studied about ANXA1 expression profile in noncancerous human gastrointestinal tissues by using RT-PCR ANXA1 was expressed in all investigated healthy tissues but the amounts varied, whereby liver showed the highest mRNA and decreased, followed by the colon, stomach, esophagus, pancreas, and bile duct, respectively. Cyclooxygenase-2 (COX-2) is an inducible enzyme which accumulates in activated macrophages and other cells at sites of inflammation. Increasing evidences showed that COX-2 was upregulated in various carcinomas and played a key role in tumorigenesis (Gao et al. 2014). Furthermore, this study also compared the expression of ANXA1 and COX-2 between noncancerous and cancerous cell, and it found that COX-2 expression in these gastric cancer cases correlated with ANXA1 expression. Immunohistochemical analysis showed a higher expression of COX-2 and a lower expression of ANXA1 in gastric tumours than those in noncancerous tissues. This profile is similar to the noncancerous tissues (Gao et al. 2014).

\section{ROLE OF ANXA1 AS A BIOMARKER IN TUMOR CELLS}

ANXA1 has important roles in oncogenic events. It acts as a productive differentiation marker in head and neck cancer. Lower level of ANXA1 in esophageal squamous cell carcinoma (ESCC) and head and neck squamous cell carcinoma (HNSCC) are linked with deficiency in cellular differentiation and indicates bigger tumour size and lymph node metastasis in HNSCC (Pedrero et al. 2004). While, lower presence of ANXA1 found in cervical cancer acts as a biological marker in determining the development of invasive cervical cancer and control of cell death related growth factor (Prates et al. 2015). In cervical cancer, ANXA1 blocks cyclin D1 and affects cell morphology, reducing the cell proliferation (Alldridge \& Bryant 2003).
It poses an immediate anti-proliferative effect on cells, and thus acts as tumour suppressor (Ang et al. 2009). Higher expression of D1 gene causes angiogenesis in ovarian cancer ( $\mathrm{Su}$ et al. 2013).

Besides, the enhanced amount of this protein links with poor prognosis in prostate cancer (Ponz-Sarvisé et al. 2014). Furthermore, rise in ANXA1 level acts as a marker for poor survival rate and enhanced tumour recurrence in esophageal squamous cell carcinoma (ESCC). Therefore, patient showing the presence of ANXA1 in nucleus indicates a bad survival rate than that of without ANXA1 nuclear expression. In controlling cell proliferation, ANXA1 nuclear translocation plays a role. Nuclear localisation of ANXA1 is a vital occurrence in ESCC, providing a prognosis factor in human cancer (Lin et al. 2008). Therefore, higher or lower level of ANXA1 in ESCC cells may show the bad prognosis for this cancer.

\section{IMPORTANCE OF ANXA1 IN IMMUNITY AGAINST INFECTION}

An in vivo study was conducted on Mycobacterium tuberculosis (Mtb) CDC1551 strain of ANXA1 deficient mice and WT mice. After the injection of Mtb bacterial strain, the lungs and spleens of the mice were removed. From the spleen, the T-cells were isolated. Bone marrow derived macrophages were characterised. Bacterial load was found to higher in ANXA1 deficient mice than WT mice. It was significantly different from WT mice with $p<0.05$. An ANXA1 deficient mouse poses bigger injury in lung and spleen as compared to wild type mice. The manifestation of inflammation is influenced by permeation of lymphocytes (Vanessa et al. 2015). TNF- $\alpha$ and IFN- $\gamma$ are involved in regulation of immunity against infection (Cruz et al. 2006).

\section{BIAS ANALYSIS}

From a total of 27 articles included in this study, it was found that five of them had potential to bias. These were due to reasons that some of the studies did not have a reliable and valid outcome. The remaining 22 articles had no risk to bias. Bias outcome was reported in Tables 3 and 4 (Supplemental data).

\section{CONCLUSION}

In conclusion, ANXA1 is found to cause apoptosis of neutrophils, inhibition of inflammatory mediators, inhibition of proinflammatory cytokines, stimulation of IL10, and blocking of NO synthesis. It is involved in cell growth, differentiation and proliferation. In addition, ANXA1 also acts as a marker in tumour cells and indicated the survival rate. Nuclear localisation of ANXA1 is a vital occurrence in OSCC providing as a 
prognosis factor in human cancer. However, in cervical cancer, ANXA1 blocked cyclin D1. Therefore, reduced the cell proliferation. It possesses an immediate antiproliferative effect on tumour suppressor cells. This study identified a potential research gap in the development of ANXA1 as a therapeutic agent in treating severe inflammation conditions and a tumour marker.

\section{ACKNOWLEDGEMENTS}

This study was funded by the Ministry of Higher Education, Malaysia for Fundamental Research Grant Scheme (FRGS), FRGS/1/2015/SKK09/UKM/02/3.

\section{REFERENCES}

Adhami, V.M., Malik, A., Zaman, N., Sarfaraz, S., Siddiqui, I.A., Syed, D.N., Afaq, F., Pasha, F.S., Saleem, M. \& Mukhtar, H. 2007. Combined inhibitory effects of green tea polyphenols and selective cyclooxygenase- 2 inhibitors on the growth of human prostate cancer cells both in vitro and in vivo. Clinical Cancer Research 13(5): 1611-1619.

Ahluwalia, A., Newbold, P., Brain, S.D. \& Flower, R.J. 1995. Topical glucocorticoids inhibit neurogenic inflammation: Involvement of lipocortin 1. European Journal of Pharmacology 283(1-3): 193-198.

Alldridge, L.C. \& Bryant, C.E. 2003. Annexin 1 regulates cell proliferation by disruption of cell morphology and inhibition of cyclin D1 expression through sustained activation of the Erk1/2 mapk signal. Experimental Cell Research 290(1): 93-107.

Ang, E.Z.F., Nguyen, H.T., Sim, H.L., Putti, T.C. \& Lim, L.H. 2009. Annexin-1 regulates growth arrest induced by high levels of estrogen in Mcf-7 breast cancer cells. Molecular Cancer Research 7(2): 266-274.

Aziz, H., Hatah, E., Bakry, M.M. \& Islahudin, F. 2016. How payment scheme affects patients' adherence to medications? A systematic review. Patient Preference and Adherence 10: 837-850.

Cronstein, B.N. \& Weissmann, G. 1993. The adhesion molecules of inflammation. Arthritis \& Rheumatology 36(2): 147-157.

Cruz, A., Khader, S.A., Torrado, E., Fraga, A., Pearl, J.E., Pedrosa, J., Cooper, A.M. \& Castro, A.G. 2006. Cutting edge: IFN-g regulates the induction and expansion of IL-17-producing CD4 T cells during mycobacterial infection. The Journal of Immunology 177(3): 1416-1420.

Ernst, S., Lange, C., Wilbers, A., Goebeler, V., Gerke, V. \& Rescher, U. 2004. An annexin $1 \mathrm{~N}$-terminal peptide activates leukocytes by triggering different members of the formyl peptide receptor family. Journal of Immunology 172(12): 7669-7676.

Fadok, V.A., Bratton, D.L., Konowal, A., Freed, P.W., Westcott, J.Y. \& Henson, P.M. 1998. Macrophages that have ingested apoptotic cells in vitro inhibit proinflammatory cytokine production through autocrine/paracrine mechanisms involving TGF-Beta, PgE2 and PAF. Journal of Clinical Investigation 101(4): 890.
Ferlazzo, V., D'agostino, P., Milano, S., Caruso, R., Feo, S., Cillari, E. \& Parente, L. 2003. Anti-inflammatory effects of annexin-1: Stimulation of IL-10 release and inhibition of nitric oxide synthesis. International Immunopharmacology 3(10-11): 1363-1369.

Ferreira, S.H., Cunha, F.Q., Lorenzetti, B.B., Michelin, M.A., Perretti, M., Flower, R.J. \& Poole, S. 1997. Role of lipocortin-1 in the anti-hyperalgesic actions of dexamethasone. British Journal of Pharmacology 121(5): 883-888.

Flower, R.J. \& Rothwell, N.J. 1994. Lipocortin-1: Cellular mechanisms and clinical relevance. Trends in Pharmacological Sciences 15(3): 71-76.

Fox, S., Leitch, A.E., Duffin, R., Haslett, C. \& Rossi, A.G. 2010. Neutrophil apoptosis: Relevance to the innate immune response and inflammatory disease. Journal of Innate Immunity 2(3): 216-227.

Gao, Y., Chen, Y., Xu, D., Wang, J. \& Yu, G. 2014. Differential expression of ANXA1 in benign human gastrointestinal tissues and cancers. BMC Cancer 14: 520.

Gerke, V., Creutz, C.E. \& Moss, S.E. 2005. Annexins: Linking $\mathrm{Ca}^{2+}$ signalling to membrane dynamics. Nature Reviews Molecular Cell Biology 6(6): 449-461.

Gibbs, L., Carollo, M.G., Damazo, A.S., Oliani, S.M. \& Perretti, M. 2002. Time-dependent expression of annexin 1 in a model of chronic granulomatous inflammation. Inflammation Research 51(6): 300-306.

Gimenes, A.D., Andrade, T.R., Mello, C.B., Ramos, L., Gil, C.D. \& Oliani, S.M. 2015. Beneficial effect of annexin A1 in a model of experimental allergic conjunctivitis. Experimental Eye Research 134: 24-32.

Hatah, E., Braund, R., Tordoff, J. \& Duffull, S.B. 2014. A systematic review and meta-analysis of pharmacist-led feefor-services medication review. British Journal of Clinical Pharmacology 77(1): 102-115.

Hirata, F., Schiffmann, E., Venkatasubramanian, K., Salomon, D. \& Axelrod, J. 1980. A phospholipase A2 inhibitory protein in rabbit neutrophils induced by glucocorticoids. Proceedings of the National Academy of Sciences USA 77(5): 2533-2536.

Ker, R.F., Wang, X.T. \& Pike, A. 2000. Fatigue quality of mammalian tendons. Journal of Experimental Biology 203(8): 1317-1327.

Kosicka, A., Cunliffe, A.D., Mackenzie, R., Zariwala, M.G., Perretti, M., Flower, R.J. \& Renshaw, D. 2013. Attenuation of plasma annexin A1 in human obesity. The FASEB Journal 27(1): 368-378.

Lim, L.H., Solito, E., Russo-Marie, F., Flower, R.J. \& Perretti, M. 1998. Promoting detachment of neutrophils adherent to murine postcapillary venules to control inflammation: Effect of lipocortin 1. PNAS 95(24): 14535-14539.

Lima, K.M., Vago, J.P., Caux, T.R., Negreiros-Lima, G.L., Sugimoto, M.A., Tavares, L.P., Arribada, R.G., Carmo, A., Galvao, I., Costa, B.R.C., Soriani, F.M., Pinho, V., Solito, E., Perretti, M., Teixeira, M.M. \& Sousa, L.P. 2017. The resolution of acute inflammation induced by cyclic amp is dependent on annexin A1. Journal of Biological Chemistry 292(33): 13758-13773. 
Lin, C.Y., Jeng, Y.M., Chou, H.Y., Hsu, H.C., Yuan, R.H., Chiang, C.P. \& Kuo, M.Y.P. 2008. Nuclear localization of annexin A1 is a prognostic factor in oral squamous cell carcinoma. Journal of Surgical Oncology 97(6): 544-550.

Lopresti, A.L. 2017. Cognitive behaviour therapy and inflammation: A systematic review of its relationship and the potential implications for the treatment of depression. Australian \& New Zealand Journal of Psychiatry 51(6): 565-582.

Lu, Q.Y., Jin, Y., Mao, J.T., Zhang, Z.F., Heber, D., Dubinett, S.M. \& Rao, J. 2012. Green tea inhibits cycolooxygenase-2 in non-small cell lung cancer cells through the induction of annexin-1. Biochemical and Biophysical Research Communications 427(4): 725-730.

Martin, G.R., Perretti, M., Flower, R.J. \& Wallace, J.L. 2008. Annexin-1 modulates repair of gastric mucosal injury. American Journal of Physiology-Gastrointestinal and Liver Physiology 294(3): G764-769.

Monastyrskaya, K., Babiychuk, E.B., Draeger, A. \& Burkhard, F.C. 2013. Down-regulation of annexin A1 in the urothelium decreases cell survival after bacterial toxin exposure. Journal of Urology 190(1): 325-333.

Ng, F.S.P., Wong, K.Y., Guan, S.P., Mustafa, F.B., Kajiji, T.S., Bist, P., Biswas, S.K., Wong, W.S.F. \& Lim, L.H.K. 2011. Annexin-1-deficient mice exhibit spontaneous airway hyperresponsiveness and exacerbated allergen-specific antibody responses in a mouse model of asthma. Clinical \& Experimental Allergy 41: 1793-1803.

Office of Health Assessment and Translation (OHAT). 2015. Handbook for Conducting a Literature-Based Health.

https://ntp.niehs.nih.gov/ntp/ohat/pubs/handbookjan2015_508. pdf. Accessed on 2 October 2017.

Oliani, S.M., Damazo, A.S. \& Perretti, M. 2002. Annexin 1 localisation in tissue eosinophils as detected by electron microscopy. Mediators of Inflammation 11(5): 287-292.

Ortega-Gómez, A., Perretti, M. \& Soehnlein, O. 2013. Resolution of inflammation: An integrated view. EMBO Molecular Medicine 5(5): 661-674.

Patel, H.B., Kornerup, K.N., Sampaio, A.L.F., D'acquisto, F., Seed, M.P., Girol, A.P., Gray, M., Pitzalis, C., Oliani, S.M. \& Perretti, M. 2012. The impact of endogenous annexin al on glucocorticoid control of inflammatory arthritis. Annals of the Rheumatic Diseases 71(11): 1872-1880.

Pedrero, J.M.G., Fernandez, M.P., Morgan, R.O., Zapatero, A.H., Gonzalez, M.V., Nieto, C.S. \& Rodrigo, J.P. 2004. Annexin A1 down-regulation in head and neck cancer is associated with epithelial differentiation status. The American Journal of Pathology 164(1): 73-79.

Pei, L., Zhang, J., Zhao, F., Su, T., Wei, H., Tian, J., Li, M. \& Shi, J. 2011. Annexin 1 exerts anti-nociceptive effects after peripheral inflammatory pain through formyl-peptidereceptor-like 1 in rat dorsal root ganglion. British Journal of Anaesthesia 107(6): 948-958.

Ponz-Sarvisé, M., Castañón, E., Panizo-Santos, A., Redrado, M., López, I., Rosell, D., Gil-Aldea, I., Calvo, A., Nguewa, P.A. \& Gil-Bazo, I. 2014. Differential tumor expression of inhibitor of differentiation-1 in prostate cancer patients with extreme clinical phenotypes and prognostic implications. Clinical Genitourinary Cancer 12(2): 87-93.

Prates, J., Franco-Salla, G.B., Dinarte Dos Santos, A.R., Da Silva Jr., W.A., Da Cunha, B.R., Tajara, E.H., Oliani, S.M. \& Rodrigues-Lisoni, F.C. 2015. Anxa1ac2-26 peptide reduces Id1 expression in cervical carcinoma cultures. Gene 570(2): 248-254.

Probst-Cousin, S., Kowolik, D., Kuchelmeister, K., Kayser, C., Neundorfer, B. \& Heuss, D. 2002. Expression of Annexin-1 in multiple sclerosis plaques. Neuropathology \& Applied Neurobiology 28(4): 292-300.

Rescher, U., Goebeler, V., Wilbers, A. \& Gerke, V. 2006. Proteolytic cleavage of annexin 1 by human leukocyte elastase. Biochimica et Biophysica Acta 1763(11): 13201324.

Rhee, H.J., Kim, G.Y., Huh, J.W., Kim, S.W. \& Na, D.S. 2000. Annexin I is a stress protein induced by heat, oxidative stress and a sulfhydryl-reactive agent. European Journal of Biochemistry 267(11): 3220-3225.

Ricciotti, E. \& Fitzgerald, G.A. 2011. Prostaglandins and inflammation. Arteriosclerosis Thrombosis and Vascular Biology 31(5): 986-1000.

Rodrigo, J.P., Garcia-Pedrero, J.M., Gonzalez, M.V., Fernandez, M.P., Suarez, C. \& Herrero, A. 2004. Expression of annexin A1 in normal and chronically inflamed nasal mucosa. Archives of Otolaryngology - Head \& Neck Surgery 130(2): 211-215.

Soehnlein, O. \& Lindbom, L. 2010. Phagocyte partnership during the onset and resolution of inflammation. Nature Reviews Immunology 10(6): 427-439.

Su, Y., Gao, L., Teng, L., Wang, Y., Cui, J., Peng, S. \& Fu, S. 2013. Id1 enhances human ovarian cancer endothelial progenitor cell angiogenesis via Pi3k/Akt and NF-kb/mmp-2 signaling pathways. Journal of Translational Medicine 11(1): 132.

Vago, J.P., Nogueira, C.R., Tavares, L.P., Soriani, F.M., Lopes, F., Russo, R.C., Pinho, V., Teixeira, M.M. \& Sousa, L.P. 2012. Annexin A1 modulates natural and glucocorticoidinduced resolution of inflammation by enhancing neutrophil apoptosis. Journal of Leukocyte Biology 92(2): 249-258.

Vanessa, K.H., Julia, M.G., Wenwei, L., Michelle, A.L., Zarina, Z.R., Lina, L.H. \& Sylvie, A. 2015. Absence of annexin A1 impairs host adaptive immunity against mycobacterium tuberculosis in vivo. Immunobiology 220(5): 614-623.

Vergnolle, N., Pages, P., Guimbaud, R., Chaussade, S., Bueno, L., Escourrou, J. \& Comera, C. 2004. Annexin 1 is secreted in situ during ulcerative colitis in humans. Inflammatory Bowel Diseases 10(5): 584-592.

Vong, L., D'acquisto, F., Pederzoli-Ribeil, M., Lavagno, L., Flower, R.J., Witko-Sarsat, V. \& Perretti, M. 2007. Annexin 1 cleavage in activated neutrophils a pivotal role for proteinase 3. Journal of Biological Chemistry 282(41): 29998-30004.

Yang, Y.H., Hutchinson, P., Santos, L.L. \& Morand, E.F. 1998. Glucocorticoid inhibition of adjuvant arthritis synovial macrophage nitric oxide production: Role of lipocortin 1. Clinical \& Experimental Immunology 111(1): 117-122. 
Yazid, S., Gardner, P.J., Carvalho, L., Chu, C.J., Flower, R.J., Solito, E., Lee, R.W., Ali, R.R. \& Dick, A.D. 2015. Annexin-A1 restricts Th17 cells and attenuates the severity of autoimmune disease. Journal of Autoimmunity 58: $1-11$.

Zhang, Z., Huang, L., Zhao, W. \& Rigas, B. 2010. Annexin 1 induced by anti-inflammatory drugs binds to NF-kB and inhibits its activation: Anticancer effects in vitro and in vivo. Cancer Research 70(6): 2379-2388.
Drug and Herbal Research Centre

Faculty of Pharmacy

Universiti Kebangsaan Malaysia

50300 Kuala Lumpur, Federal Territory

Malaysia

*Corresponding author; email: e_kumolosasi@ukm.edu.my

Received: 23 April 2020

Accepted: 1 July 2020

\section{SUPPLEMENTAL DATA}

TABLE 1. Summary of in vivo studies

\begin{tabular}{|c|c|c|c|c|c|}
\hline Author (year) & Animal model & $\begin{array}{l}\text { Treatment/ } \\
\text { Chemical }\end{array}$ & Method & Results & Comment \\
\hline $\begin{array}{l}\text { Lim et al. } \\
\text { (1998) }\end{array}$ & $\begin{array}{c}\text { Male swiss albino } \\
\text { mice }\end{array}$ & Zymosan & $\begin{array}{l}\text { Mice were injected } \\
\text { with zymosan and then } \\
\text { treated with human } \\
\text { recombinant ANXA1 } \\
\text { and mimetic peptide } \\
\text { Ac2-26 } \\
\text { This protein was } \\
\text { purified by fast protein } \\
\text { liquid chromatography }\end{array}$ & $\begin{array}{l}\text { Zymosan caused } \\
\text { rise in cell adhesion } \\
\text { and emigration } \\
\text { ANXA1 and } \\
\text { mimetic peptide } \\
\text { Ac2-26 caused } \\
\text { detachment of } \\
\text { leukocytes }\end{array}$ & $\begin{array}{l}\text { ANXA1 blocks } \\
\text { adherent } \\
\text { neutrophils } \\
\text { from going into } \\
\text { the diapedesis } \\
\text { and at the end } \\
\text { detaches it from } \\
\text { post capillary } \\
\text { venule }\end{array}$ \\
\hline $\begin{array}{l}\text { Martin et al. } \\
(2008)\end{array}$ & Male C57L6 mice & Ac2-26 and Boc2 & $\begin{array}{l}\text { Gastric ulcers were } \\
\text { induced using acetic } \\
\text { acid in the mice and } \\
\text { western blot carried out } \\
\text { to analyze ANXA1 } \\
\text { Tissue samples } \\
\text { incubated with ANXA1 } \\
\text { polyclonal antibody } \\
\text { WT and ANXA1 } \\
\text { deficient mice } \\
\text { were treated with } \\
\text { indomethacin to } \\
\text { evaluate the severity }\end{array}$ & $\begin{array}{c}\text { ANXA1 was } \\
\text { expressed highly } \\
\text { in ulcer induced } \\
\text { mice. In non- ulcer } \\
\text { induced mice, the } \\
\text { level is low } \\
\text { Treatment upon } \\
\text { Ac2-26 showed } \\
\text { an increase in the } \\
\text { healing of ulcer } \\
\text { but showed the } \\
\text { opposite when } \\
\text { treated Boc-2 }\end{array}$ & $\begin{array}{l}\text { ANXA1 helps } \\
\text { in the repair of } \\
\text { gastric mucosal } \\
\text { injury. Ac2-26 } \\
\text { has improved } \\
\text { healing }\end{array}$ \\
\hline $\begin{array}{l}\text { Gibbs et al. } \\
(2002)\end{array}$ & Female TO mice & $\begin{array}{l}0.1 \% \text { croton oil in } \\
\text { Freund's complete } \\
\text { adjuvant }(\mathrm{CO} / \mathrm{FCA})\end{array}$ & $\begin{array}{c}\text { Tissues were } \\
\text { extracted and used for } \\
\text { examination of protein } \\
\text { and mRNA } \\
\text { Western blotting was } \\
\text { carried out to detect the } \\
\text { protein } \\
\text { Total RNA was isolated } \\
\text { by electrophoresis. } \\
\text { Hybridization was } \\
\text { carried out }\end{array}$ & $\begin{array}{l}\text { There was no } \\
\text { difference between } \\
37 \mathrm{kDa} \text { and } 33 \mathrm{kDa} \\
\text { proteins being } \\
\text { expressed in } \\
\text { inflamed tissue } \\
\text { The expression was } \\
\text { increased. Through } \\
\text { northern blotting, } \\
\text { mRNA expression } \\
\text { was determined }\end{array}$ & $\begin{array}{l}\text { Infiltrate } \\
\text { neutrophils } \\
\text { are important } \\
\text { in ANXA1 } \\
\text { expression } \\
\text { and its level is } \\
\text { significantly } \\
\text { increased } \\
\text { during } \\
\text { inflammation }\end{array}$ \\
\hline
\end{tabular}


Blood samples were centrifuged. Detection on the localization of ANXA1 from the inflamed tissue
PMN and MNC were increased in inflamed tissue

\section{Plasma}

corticosterone level was enhanced in animals with $\mathrm{CO} /$

FCA

Sheep serum

antibody was able

to detect both

$33 \mathrm{kDa}$ and $37 \mathrm{kDa}$

\begin{tabular}{lcc}
\hline Yang et al. & Male Sprague Dawley & Dexamethasone \\
$(1998)$ & rats
\end{tabular}
By injection, adjuvant arthritis (AA) induced inflammation in the mice. The synovial tissue was isolated from knee and hind foot.

Through this tissue, synovial macrophages were obtained. Cells were treated with dexamethasone, LPS and anti- lipocortin-1. Nitric oxide released in macrophages was determined.

Dexamethasone was added to the cells.

Western blot was used to analyse the protein

Upon
inflammation,

NO is produced

in the AA. When

dexamethasone was

given, it inhibited

NO production

The synovial macrophages in AA showed a presence of lipocortin-1.

This content

was increased

further with the

administration of

dexamethasone

\author{
$\mathrm{LC} 1$ is an \\ important \\ mediator of \\ glucocorticoid \\ to produce \\ its anti- \\ inflammatory \\ actions upon \\ synovial \\ macrophages
}

\begin{tabular}{|c|c|c|c|}
\hline $\begin{array}{l}\text { Ahluwalia et } \\
\text { al. (1995) }\end{array}$ & Male wistar rat & $\begin{array}{c}\text { Betamethasone- } 17- \\
\text { valerate }\end{array}$ & $\begin{array}{l}\text { Skin of hind paw } \\
\text { was treated with } \\
\text { betamethasone- 17- } \\
\text { valerate to determine } \\
\text { the effect of steroid on } \\
\text { treating oedema }\end{array}$ \\
\hline
\end{tabular}

Glucocorticoids blocked

oedemaformation

in rats. Treatment

upon antiserum

to lipocortin-1

has reversed the

inhibitory effect by $29 \%$
When

glucocorticoid

is applied

upon any

inflammatory

condition,

lipocortin- 1 is

induced on the

cell surface

\begin{tabular}{lcc}
\hline $\begin{array}{l}\text { Oliani et al. Male Sprague Dawley } \\
\text { (2002) }\end{array}$ & Carragenin & Mice were treated with \\
& & anti ANXA1 antibodies \\
& Localization of ANXA1 \\
& in tissue eosinophils \\
& was detected by \\
& electron microscope
\end{tabular}

$\begin{array}{cc}\text { After injecting } & \text { ANXA1 is } \\ \text { carragenin, the } & \text { found in } \\ \text { expression of } & \text { a major } \\ \text { ANXA1 was } & \text { portion in rat } \\ \text { increased in the } & \text { eosinophils } \\ \text { cytoplasm } & \end{array}$

Percentage of

ANXA1 found in

eosinophil cytosol

was majority

whereas only

small portion was

found in plasma

membrane 


\begin{tabular}{|c|c|c|c|c|c|}
\hline $\begin{array}{l}\text { Pei et al. } \\
\text { (2011) }\end{array}$ & $\begin{array}{l}\text { Male Sprague Dawley } \\
\text { rat }\end{array}$ & CFA & $\begin{array}{l}\text { CFA was injected into } \\
\text { dorsal surface of rat's } \\
\text { left hindpaw to induce } \\
\text { inflammation. } \\
\text { ANXA 12-26, BML-111 } \\
\text { and Boc-1 peptides } \\
\text { were used to determine } \\
\text { the characterization } \\
\text { of FPR2/ALX in anti- } \\
\text { nociception of ANXA1 } \\
\text { Western blot analysis } \\
\text { was carried out to } \\
\text { determine the protein } \\
\text { expression }\end{array}$ & $\begin{array}{c}\text { Treatment with } \\
\text { CFA has enhanced } \\
\text { the expression of } \\
\text { ANXA1 } \\
\text { ANXA1 released } \\
\text { its anti nociceptive } \\
\text { effect via FPR2/ } \\
\text { ALX } \\
\text { ANXA1 and FPR2/ } \\
\text { ALX were found to } \\
\text { be in satellite glial } \\
\text { cells and neurons }\end{array}$ & $\begin{array}{l}\text { ANXA1 derived } \\
\text { peptide is able } \\
\text { to enhance } \\
\text { the ANXA1 } \\
\text { expression }\end{array}$ \\
\hline $\begin{array}{l}\text { Patel et al. } \\
\text { (2012) }\end{array}$ & $\begin{array}{l}\mathrm{BALB} / \mathrm{c} \text { wild type } \\
\text { mice }\end{array}$ & Dexamethasone & $\begin{array}{l}\text { Mice were treated by } \\
\text { K/BxN serum to induce } \\
\text { inflammatory arthritis. } \\
\text { Next, mice were given } \\
\text { dexamethasone and } \\
\text { some treated with } \\
\text { ANXA1 } \\
\text { mRNA and protein } \\
\text { expression in the ankle } \\
\text { joint were observed } \\
\text { by RT- PCR and } \\
\text { immunohistochemistry }\end{array}$ & $\begin{array}{l}\text { Treatment with } \\
\text { dexamethasone } \\
\text { has caused the } \\
\text { induction of } \\
\text { ANXA1 in tissue } \\
\text { Mice with ANXA1 } \\
\text { deficiency did not } \\
\text { show improvement } \\
\text { in inflammation } \\
\text { whereas mice } \\
\text { with presence of } \\
\text { ANXA1 has shown } \\
\text { improvement }\end{array}$ & $\begin{array}{l}\text { ANXA1 is vital } \\
\text { to predict the } \\
\text { efficacy of } \\
\text { glucocorticoids }\end{array}$ \\
\hline $\begin{array}{l}\text { Gimenes et al. } \\
(2015)\end{array}$ & $\begin{array}{c}\text { Male wild type and } \\
\text { ANXA1 knockout } \\
\text { BALB/c mice }\end{array}$ & Ovalbumin & $\begin{array}{c}\text { Mice were pre } \\
\text { treated with Ac2-26 } \\
\text { and dexamethasone } \\
\text { before ovalbumin was } \\
\text { administered } \\
\text { Severity of } \\
\text { conjunctivitis was } \\
\text { observed. Level of } \\
\text { IgGwas measured. } \\
\text { Expression of ANXA1 } \\
\text { in ocular tissues was } \\
\text { measured by using } \\
\text { western blot analysis }\end{array}$ & $\begin{array}{l}\text { When OVA was } \\
\text { given in WT and } \\
\text { ANXA1 deficient } \\
\text { mice, they } \\
\text { presented with } \\
\text { moderate to severe } \\
\text { conjunctivitis } \\
\text { Upon } \\
\text { treatment with } \\
\text { dexamethasone and } \\
\text { Ac2-26 mimetic } \\
\text { peptide, it reduced } \\
\text { the severity } \\
\text { Thus, the IgE level } \\
\text { was increased } \\
\text { when it was treated } \\
\text { with OVA alone } \\
\text { but the level then } \\
\text { reduced when } \\
\text { dexamethasone and } \\
\text { Ac2-26 mimetic } \\
\text { peptide were given }\end{array}$ & $\begin{array}{l}\text { ANXA1 } \\
\text { controls the } \\
\text { progression of } \\
\text { conjunctivitis } \\
\text { by inhibiting } \\
\text { the activation } \\
\text { of eosinophils, } \\
\text { mast cells and } \\
\text { neutrophils }\end{array}$ \\
\hline
\end{tabular}




\begin{tabular}{|c|c|c|c|c|c|c|}
\hline $\begin{array}{l}\text { Vanessa et al. } \\
(2015)\end{array}$ & \multicolumn{2}{|c|}{$\begin{array}{l}\text { Balb/c WT and } \\
\text { NXA1 deficient mice }\end{array}$} & $\begin{array}{c}\text { L } \\
\mathrm{L} \\
\text { an } \\
\mathrm{B} \\
\mathrm{de} \\
\mathrm{m}\end{array}$ & $\begin{array}{l}\text { Mice were infected } \\
\text { with mtb CD1551 } \\
\text { bacterial strain. } \\
\text { Lung and spleen were } \\
\text { isolated. Histological } \\
\text { nalysis was conducted } \\
\text { Bone marrow derived } \\
\text { lendritic cells (BMDCs) } \\
\text { were obtained from } \\
\text { mice and T cells were } \\
\text { isolated }\end{array}$ & $\begin{array}{l}\text { Cells of infected } \\
\text { lung and spleen of } \\
\text { ANXA1 deficient } \\
\text { mice showed an } \\
\text { increase in bacterial } \\
\text { load compared to } \\
\text { WT mice } \\
\text { In ANXA1 deficient } \\
\text { mice, inflammation } \\
\text { was characterized } \\
\text { by infiltration and } \\
\text { aggregation of } \\
\text { lymphocytes and } \\
\text { macrophages } \\
\text { For WT mice, } \\
\text { inflammation was } \\
\text { more characterized } \\
\text { and restricted to } \\
\text { vascular associated } \\
\text { focal lesions }\end{array}$ & $\begin{array}{c}\text { Absence of } \\
\text { lipocortin- } 1 \\
\text { interferes with } \\
\text { the adaptive } \\
\text { immunity in } \\
\text { the presence of } \\
\text { bacteria }\end{array}$ \\
\hline $\begin{array}{l}\text { Yazid et al. } \\
(2015)\end{array}$ & $\begin{array}{l}\text { C57b1/6 } \\
\text { and B10. } \\
\text { RIII mice }\end{array}$ & $\begin{array}{l}\text { Human } \\
\text { recombinant } \\
\text { ANXA1 }\end{array}$ & $\begin{array}{c}\text { Mice were } \\
\text { administered with } \\
\text { human recombinant } \\
\text { ANXA1 } \\
\text { Lens and retina } \\
\text { were dissected and } \\
\text { purified rat anti } \\
\text { mouse CD16/CD } 32 \\
\text { monoclonal antibody } \\
\text { was added } \\
\text { Western blot analysis } \\
\text { was carried out to } \\
\text { assess protein. RNA } \\
\text { detection was done } \\
\text { by PCR }\end{array}$ & $\begin{array}{c}\text { Mice with ANXA1 } \\
\text { deficiency showed } \\
\text { more retinal } \\
\text { inflammation to } \\
\text { that of wild type } \\
\text { mice } \\
\text { ANXA1 deficient } \\
\text { mice showed } \\
\text { an increase in } \\
\text { monocytes, } \\
\text { neutrophils and } \\
\text { macrophages } \\
\text { When this protein } \\
\text { was present, } \\
\text { it attenuated } \\
\text { the severity of } \\
\text { inflammation } \\
\text { It also caused the } \\
\text { alterations in T } \\
\text { cell differentiation } \\
\text { and proliferation }\end{array}$ & $\begin{array}{l}\text { In a condition } \\
\text { autoimmune pat } \\
\text { deficient mice poss } \\
\text { Th17 and }\end{array}$ & $\begin{array}{l}\text { f enhanced } \\
\text { way, ANXA1 } \\
\text { ss an increase in } \\
\text { 1L-17 }\end{array}$ \\
\hline $\begin{array}{l}\text { Ferreira et al. } \\
(1997)\end{array}$ & $\begin{array}{c}\text { Male } \\
\text { wistar rat }\end{array}$ & $\begin{array}{c}\text { PGE2, } \\
\text { carrageenin, } \\
\text { bradykinin, } \\
\text { TNF alpha, IL-1 } \\
\text { beta, dopamine, } \\
\text { dexamethasone, } \\
\text { lipocortin-12-26 }\end{array}$ & $\begin{array}{l}\text { Rats were injected } \\
\text { with PGE2, } \\
\text { carrageenin, } \\
\text { bradykinin, TNF } \\
\text { alpha, IL-1 beta and } \\
\text { dopamine to induce } \\
\text { hyperalgesic effect } \\
\text { The rats were } \\
\text { then injected with } \\
\text { dexamethasone and } \\
\text { lipocortin- } 12-26\end{array}$ & $\begin{array}{l}\text { Hyperalgesic was } \\
\text { induced upon } \\
\text { administration of } \\
\text { PGE2, carrageenin, } \\
\text { bradykinin, TNF } \\
\text { alpha, IL-1 beta, } \\
\text { and dopamine } \\
\text { Dexamethasone } \\
\text { induced } \\
\text { lipocortin-1 thus } \\
\text { inhibited the } \\
\text { hyperalgesic effect }\end{array}$ & $\begin{array}{l}\text { ANXA1 mediates } \\
\text { presence of dexame } \\
\text { blocks the cytoki } \\
\text { hyperalgesic }\end{array}$ & $\begin{array}{l}\text { ts effect by the } \\
\text { hasone and thus } \\
\text { es involved in } \\
\text { nd COX-2 }\end{array}$ \\
\hline
\end{tabular}




\begin{tabular}{|c|c|c|c|c|c|}
\hline $\begin{array}{l}\text { Ng et al. } \\
(2011)\end{array}$ & $\begin{array}{l}\text { ANXA1 } \\
\text { deficient } \\
\text { and WT } \\
\text { mice }\end{array}$ & Ovalbumin & $\begin{array}{l}\text { Mice were injected } \\
\text { with ovalbumin. } \\
\text { Airway resistance } \\
\text { and lung compliance } \\
\text { were measured }\end{array}$ & $\begin{array}{l}\text { Total IgE, IgG2a } \\
\text { and IgG2b levels } \\
\text { were observed } \\
\text { higher in ANXA1 } \\
\text { deficient mice } \\
\text { compared to WT } \\
\text { mice }\end{array}$ & $\begin{array}{l}\text { Lack in presence of ANXA1 leads to } \\
\text { clinical changes in allergic asthma }\end{array}$ \\
\hline $\begin{array}{l}\text { Vago et al. } \\
\text { (2012) }\end{array}$ & $\begin{array}{c}\text { Male } \\
\text { BALB/c } \\
\text { mice }\end{array}$ & $\begin{array}{c}\text { Rolipram, } \\
\text { Dexamethasone }\end{array}$ & $\begin{array}{c}\text { Injection of } \\
\text { lipopolysaccharides } \\
\text { (LPS) into the mice } \\
\text { and then pleural } \\
\text { cavity cells were } \\
\text { harvested. } \\
\text { Rolipram and } \\
\text { dexamethasone were } \\
\text { given to mice. 4h } \\
\text { LPS-challenged mice } \\
\text { were given peptide } \\
\text { Ac2-26 to lower } \\
\text { inflammation. } \\
\text { Cell death } \\
\text { of leukocyte } \\
\text { was evaluated } \\
\text { morphologically. } \\
\text { The products } \\
\text { from cell lysis } \\
\text { were prepared } \\
\text { with incubation of } \\
\text { primary antibody } \\
\text { and analyzed by } \\
\text { western blot }\end{array}$ & $\begin{array}{c}\text { Neutrophil } \\
\text { recruitment } \\
\text { induced by LPS } \\
\text { showed drop in } \\
\text { ANXA1 expression } \\
\text { Rolipram reduced } \\
\text { amount of } \\
\text { neutrophil and } \\
\text { increased cell } \\
\text { death events. It } \\
\text { also increased } \\
\text { levels of ANXA1 } \\
\text { ANXA1 is } \\
\text { expressed during } \\
\text { natural and drug- } \\
\text { induced resolution } \\
\text { of inflammation }\end{array}$ & $\begin{array}{c}\text { During natural and GC- induced } \\
\text { resolution of inflammation, ANXA1 } \\
\text { plays an important role in inducing } \\
\text { the cell death of inflammatory } \\
\text { cells thus promoting apoptosis of } \\
\text { neutrophils }\end{array}$ \\
\hline
\end{tabular}

TABLE 2. Summary of in vitro studies

\begin{tabular}{|c|c|c|c|c|}
\hline Author (year) & $\begin{array}{l}\text { Cell/ tissue model } \\
\text { (cell type) }\end{array}$ & Method & Results & Comment \\
\hline $\begin{array}{l}\text { Rodrigo et al. } \\
(2004)\end{array}$ & $\begin{array}{l}\text { Mucosa tissue (from } \\
\text { middle turbinate) } \\
\text { in healthy patient } \\
\text { and patient with } \\
\text { perennial rhinitis. } \\
\text { Nasal polyp from } \\
\text { patient undergoing } \\
\text { polypectomy }\end{array}$ & $\begin{array}{l}\text { All tissue samples were } \\
\text { treated in alcohol and } \\
\text { embedded in paraffin } \\
\text { Immunohistochemical } \\
\text { study was conducted } \\
\text { to examine the ANXA1 } \\
\text { expression }\end{array}$ & $\begin{array}{c}\text { It was found that ANXA1 } \\
\text { was expressed in a high } \\
\text { level by the ciliated cells. } \\
\text { It was found more in the } \\
\text { apical surface and within } \\
\text { cilia } \\
\text { The level of expression of } \\
\text { ANXA1 was the same in } \\
\text { epithelial cells and glands } \\
\text { of normal and chronically } \\
\text { inflamed nasal mucosa }\end{array}$ & $\begin{array}{l}\text { Expression of ANXA1 in } \\
\text { respiratory epithelium of } \\
\text { nasal mucosa is related to } \\
\text { cell type and differentiation } \\
\text { and not being influenced by } \\
\text { inflammatory disease }\end{array}$ \\
\hline
\end{tabular}




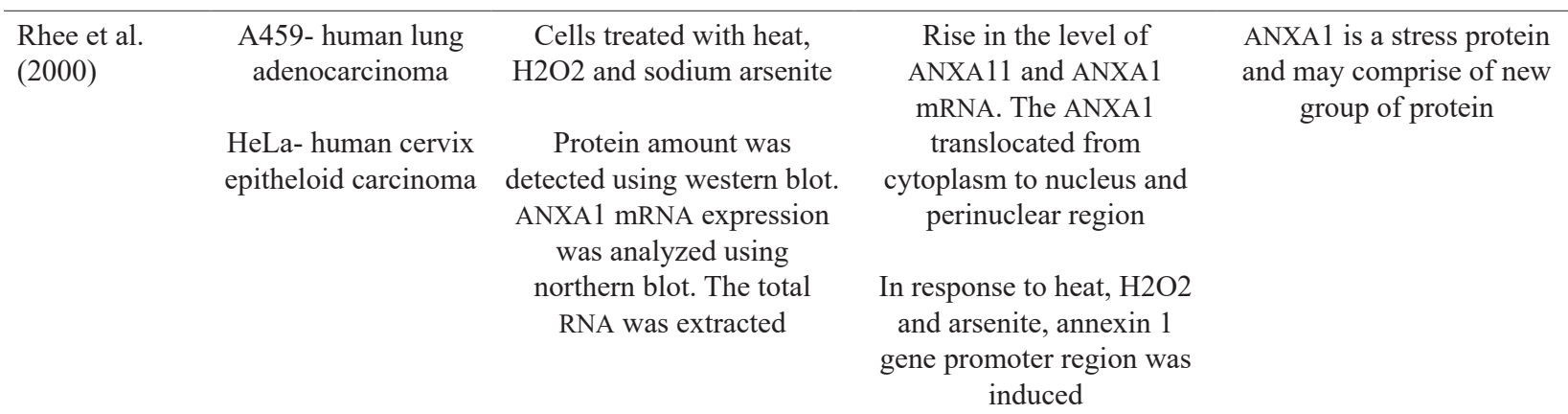

\begin{tabular}{lc}
\hline $\begin{array}{l}\text { Ferlazzo et al. } \\
\text { (2003) }\end{array}$ & Cell line J774 was cultured. \\
& NO and cytokines were \\
& measured. IL-10 was \\
determined by enzyme- & linked immunosorbent \\
& assay (ELISA) \\
& Cultures were treated with \\
Ac2 -26 and incubated in \\
LPS. RNA was isolated and \\
analyzed by RT-PCR
\end{tabular}

\section{Addition of human \\ recombinant $\mathrm{ANX}-1$ \\ stimulated release of IL-10}

Annexin 1 and its peptide derivative prevented the release of NO and IL-12 mRNA

It is due to the antiinflammatory effect of annexin 1 mediated by IL-10 thus inhibiting iNOS

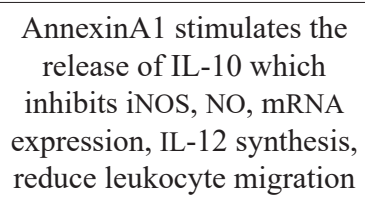

\begin{tabular}{lc}
\hline Lin et al. & SAS cell line \\
$(2008)$ & $\begin{array}{c}\text { Presence of ANXA1 } \\
\text { was determined } \\
\text { immunohistochemically }\end{array}$
\end{tabular}

Monastyrskaya UE cell line TEUet al. (2013) 2 and human bronchial epithelial cell line
Cells were cultured and transepithelial electrical resistance was measured Quantitative reverse transcriptase- PCR and immunofluorescene was conducted to analyze the annexin expression in the bladder layers. RNA was isolated

Cells were evaluated on survival and differentiation after being exposed to pore forming bacterial toxin streptolysin $\mathrm{O}$ using microscope and alamar Blue assay
Expression of Annexin A1 was found high in UE. Due to the cell differentiation from TEU-2, this protein was up regulated

Cell survival was drastically reduced due to siRNA capture after bacterial toxin exposure and found in lower level in BPS patients
The reduction in this protein leads to declination of UE cell survival and causes progress of BPS

\section{Nuclear isolation of ANXA1 is a repeated event and vital prognostic factor in OSCC} size and further metastasis indicating bad survival rate

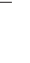

'




\begin{tabular}{|c|c|c|c|}
\hline $\begin{array}{l}\text { Rescher et al. } \\
(2006)\end{array}$ & $\begin{array}{l}\text { Human endothelial } \\
\text { hybrid cell line } \\
\text { EAhy. } 926\end{array}$ & $\begin{array}{l}\text { Blood leukocytes and } \\
\text { endothelial cells were } \\
\text { isolated. Purified Annexin } \\
\text { A1 was inserted to } \\
\text { leukocytes. Western } \\
\text { blotting was done to } \\
\text { determine Annexin A1 } \\
\text { by adding anti-ANXA1 } \\
\text { polyclonal antibody. } \\
\text { It produced intact } \\
\text { and cleaved parts of } \\
\text { Annexina1. Purified human } \\
\text { recombinant Annexin } \\
\text { A1 was cultured with } \\
\text { recombinant HLE }\end{array}$ & $\begin{array}{c}\text { Annexin A1 originally is of } \\
37 \mathrm{kDa} \text { but it was cleaved } \\
\text { to } 33 \mathrm{kDa} \text { once treated with } \\
\text { HLE thus promoting it as a } \\
\text { substrate for HLE } \\
\text { When PMN was treated } \\
\text { with human recombinant } \\
\text { Annexin a1, it does not } \\
\text { cause the degradation of } \\
\text { Annexin A1 }\end{array}$ \\
\hline
\end{tabular}

\begin{tabular}{|c|c|c|c|}
\hline $\begin{array}{l}\text { Prates et al. } \\
(2015)\end{array}$ & $\begin{array}{l}\text { SiHa cell line } \\
\text { (epidermoid } \\
\text { carcinoma of cervix) }\end{array}$ & $\begin{array}{c}\text { Ac2-26 peptide was added } \\
\text { to the cell and served as } \\
\text { experimental group and } \\
\text { the morphology was seen. } \\
\text { The control group was not } \\
\text { manipulated } \\
\text { RNA was isolated from both } \\
\text { groups. Rapid subtraction } \\
\text { hybridization (RaSH) was } \\
\text { conducted. Both strands of } \\
\text { DNA was synthesized and } \\
\text { obtained } \\
\text { The gene expression was } \\
\text { analyzed by PCR }\end{array}$ & $\begin{array}{c}\text { There was inhibition of } \\
\text { cell proliferation in SiHa } \\
\text { cell by Ac2-26. From the } \\
\text { genes observed, } 55 \text { of } \\
\text { them showed changes in } \\
\text { expression when treated } \\
\text { with peptide } \\
\text { Five of the up regulated } \\
\text { genes were TPT1, LDHA, } \\
\text { NCOA3, HIF1A, RAB13 } \\
\text { and one gene was down } \\
\text { regulated which was ID1. } \\
\text { These five genes play } \\
\text { role in tumorigenic and } \\
\text { inflammatory process } \\
\text { BMRP1B gene from the } \\
\text { ID1 pathway also down } \\
\text { regulated }\end{array}$ \\
\hline
\end{tabular}

\begin{tabular}{llr}
\hline Lu et al. & Lung cancer & Cell proliferation was \\
(2012) & A549, NCI-H460 & conducted using those \\
and NCI- H157, & cells and treated green tea \\
non neoplastic & extract (GTE). All cells \\
bronchial & were treated with primary \\
epithelial BEAS- & antibodies and immunoblot \\
2B cell & analysis was carried out. \\
line (ATCC) & Total RNA was isolated \\
& & using a chemical
\end{tabular}

By treating these cells with GTE, it blocked the A549 cell proliferation. It also caused increase in ANXA1 expression when treated with $\mathrm{H} 157$ Both H460 and H157 caused increase in ANXA1 and mRNA expression

When cells of A549 and H460 treated with GTE, the ANXA1 was increased while COX-2 and PLA2 was decreased

The level of COX-2 decreased due to the induction of ANXA1 production. When COX- 2 was up regulated, it over produces PGE2
Annexin A1 acts as a substrate for HLE it helps in controlling leukocyte emigration to inflammatory sites via its cleaved peptide

\author{
This protein's peptide \\ changes the proliferation in \\ $\mathrm{SiHa}$ cells and serves it as a \\ therapy for treating cervical \\ carcinoma
}

\author{
GTE has shown its role \\ in inflammation by \\ expressing ANXA1 in \\ different type of cancer \\ cells and this avoids cancer \\ and other inflammatory \\ diseases
}




\begin{tabular}{|c|c|c|c|c|}
\hline $\begin{array}{l}\text { Ernst et al. } \\
(2004)\end{array}$ & $\begin{array}{l}\text { Human embryonic } \\
\text { kidney (HEK) } 293 \\
\text { cells }\end{array}$ & $\begin{array}{l}\text { The mimetic peptide of } \\
\text { Annexin } 1 \text { (Ac1-25) was } \\
\text { used. Extraction of blood } \\
\text { granulocytes and monocytes } \\
\text { were done } \\
\text { Human granulocytes and } \\
\text { monocytes were treated } \\
\text { with Ac1-25 } \\
\text { By using PCR, cDNAs } \\
\text { encoding FPR } 1 \text { and FPR } 2 \\
\text { were achieved } \\
\text { A chemotaxis assay } \\
\text { was conducted for the } \\
\text { movement of human } \\
\text { monocytes, HEK } 293 \text { cells } \\
\text { which express FPR, FPRL1 } \\
\text { or FPRL2 or parental nnzsa } \\
293 \text { cells }\end{array}$ & $\begin{array}{l}\text { Annexin A1 exerted its } \\
\text { anti inflammatory action } \\
\text { through the N- terminal } \\
\text { peptide Ac1-25 and acted } \\
\text { as chemoattractant } \\
\text { It activated human } \\
\text { leukocytes and triggered } \\
\text { chemotaxis by operating } \\
\text { FPR and its family } \\
\text { members. } \\
\text { ANXA1 changed the } \\
\text { morphology of neutrophils }\end{array}$ & $\begin{array}{l}\text { ANXA1 acts as the ligand } \\
\text { to FPR family and it is } \\
\text { involved in controlling } \\
\text { leukocyte movement } \\
\text { into the inflamed area by } \\
\text { activating or deactivating } \\
\text { the FPR }\end{array}$ \\
\hline
\end{tabular}

\begin{tabular}{llc}
\hline $\begin{array}{l}\text { Hirata et al. } \\
\text { (1980) }\end{array}$ & $\begin{array}{l}\text { Rabbit peritoneal } \\
\text { neutrophils }\end{array}$ \\
& Reutrophils were prepared \\
with glucocorticoids. & The action of PLA2 \\
activity was evaluated by \\
the liberation of arachidonic \\
acid from the cellular lipids. \\
Bovine serum albumin was \\
also used. The assay of \\
porcine pancreatic PLA2 \\
was done
\end{tabular}

The effect of glucocorticoid was measured by observing

the specific uptake

of dexamethasone in neutrophils

The protein was isolated from the neutrophils
When the neutrophil was
treated with glucocorticoid,
it lowered the release and synthesis of prostaglandins by blocking the pathway
This protein has the ability to block the PLA2 pathway thus reducing the chemotactic response of neutrophils of PLA2

The release of arachidonic acid was influenced by the different types of steroids used

The percentage of inhibition varied Flucinoloneacetonide was found to have the highest percentage of inhibition. Inhibitory effect occured via cytoplasmic glucocorticoid receptors

\begin{tabular}{llcc}
\hline $\begin{array}{l}\text { Probst- } \\
\text { Cousin et al. } \\
(2002)\end{array}$ & $\begin{array}{l}\text { Tissue samples from } \\
10 \text { patients with MS } \\
\text { and five samples from } \\
\text { patients without any } \\
\text { neurological diseases }\end{array}$ & $\begin{array}{c}\text { Immunohistochemistry was } \\
\text { done }\end{array}$ & $\begin{array}{c}\text { The presence of Annexin } \\
1 \text { was detected majorly in } \\
\text { ependymal, subependymal, } \\
\text { meninges, neurons and } \\
\text { astrocytes }\end{array}$ \\
& $\begin{array}{c}\text { The expresion of ANXA1 } \\
\text { was detect }\end{array}$ & $\begin{array}{c}\text { This protein was not found } \\
\text { in the white matter }\end{array}$ \\
& $\begin{array}{l}\text { In MS cells, the presence } \\
\text { of this protein was linked } \\
\text { with the lesions where it } \\
\text { is significantly reduced } \\
\text { from active lesions through } \\
\text { chronic stages }\end{array}$
\end{tabular}

Presence of ANXA1 is linked with fresh MS lesions and it is stage reliant in the plaques

\section{chronic stages}




\begin{tabular}{|c|c|c|c|c|}
\hline $\begin{array}{l}\text { Vergnolle et } \\
\text { al. }(2004)\end{array}$ & $\begin{array}{l}\text { Tissue samples from } \\
\text { healthy patients, slight } \\
\text { UC, moderate UC, } \\
\text { severe UC inflamed } \\
\text { and severe UC of } \\
\text { healthy colon }\end{array}$ & $\begin{array}{l}\text { All the tissue samples } \\
\text { were obtained from the } \\
\text { patients receiving anti- } \\
\text { inflammatory therapy } \\
\text { All the specimen were } \\
\text { inoculated in culture } \\
\text { medium and washed with } \\
\text { normal saline to remove } \\
\text { presence of ANXA1 in the } \\
\text { cell surface } \\
\text { ANXA1 was then observed } \\
\text { using western blotting }\end{array}$ & $\begin{array}{l}\text { The MPO activity was } \\
\text { observed Tissue samples } \\
\text { from patient with severe } \\
\text { UC of inflamed colon had } \\
\text { the highest MPO activity } \\
\text { whereas samples from } \\
\text { severe UC with healthy } \\
\text { colon had lowest MPO } \\
\text { activity } \\
\text { ANXA1 was secreted in } \\
\text { a high amount in severe } \\
\text { UC condition whereas not } \\
\text { detected in healthy samples }\end{array}$ & $\begin{array}{l}\text { Annexin } 1 \text { is being } \\
\text { released during the UC } \\
\text { condition of inflamed } \\
\text { colons }\end{array}$ \\
\hline $\begin{array}{l}\text { Ferreira et al. } \\
\text { (1997) }\end{array}$ & $\begin{array}{l}\text { J774 murine } \\
\text { macrophages }\end{array}$ & $\begin{array}{l}\text { The cells were cleaned with } \\
\text { normal saline and added } \\
\text { with LPS, lipocortin- } 12-26 \\
\text { and dexamethasone }\end{array}$ & $\begin{array}{c}\text { These cells blocked TNF- } \alpha \\
\text { which was produced by } \\
\text { J774 cell }\end{array}$ & $\begin{array}{l}\text { ANXA1 mediates its } \\
\text { effect by the presence } \\
\text { of dexamethasone and } \\
\text { thus blocks the cytokines } \\
\text { involved in hyperalgesic } \\
\text { and COX-2 } \\
\text { The anti- inflammatory role } \\
\text { of lipocortin is within its } \\
\text { peptide lipocortin- } 12-26\end{array}$ \\
\hline $\begin{array}{l}\text { Kosicka et al. } \\
\text { (2013) }\end{array}$ & $\begin{array}{l}\text { Blood samples from } \\
\text { healthy and obese } \\
\text { patients }\end{array}$ & $\begin{array}{l}\text { ANXA1 level was measured } \\
\text { in the human plasma } \\
\text { Positive control was served } \\
\text { with human neutrophils }\end{array}$ & $\begin{array}{l}\text { Plasma ANXA1 was } \\
\text { inversely proportional to } \\
\text { the BMI indicating that } \\
\text { as fat lump increases, the } \\
\text { level of ANXA1 decreases }\end{array}$ & $\begin{array}{l}\text { Diminished level of } \\
\text { ANXA1 was present in } \\
\text { overweight and obese } \\
\text { patients }\end{array}$ \\
\hline
\end{tabular}

TABLE 3. Summary of risk of bias ratings for in vivo studies

\begin{tabular}{|c|c|c|c|c|c|}
\hline Risk of bias/Author & $\begin{array}{l}\text { Selection } \\
\text { bias }\end{array}$ & Performance bias & Exclusion bias & $\begin{array}{c}\text { Detection } \\
\text { bias }\end{array}$ & $\begin{array}{c}\text { Reporting } \\
\text { bias }\end{array}$ \\
\hline Vago et al. (2012) & + & + & + & + & + \\
\hline Lim et al. (1998) & + & + & + & + & + \\
\hline Martin et al. (2008) & + & + & + & + & + \\
\hline Gibbs et al. (2002) & + & + & + & - & + \\
\hline Yang et al. (1998) & + & + & + & + & + \\
\hline Ahluwalia et al. (1995) & + & + & + & + & + \\
\hline Oliani et al. (2002) & + & + & $?$ & - & + \\
\hline Pei et al. (2011) & + & + & + & + & + \\
\hline Patel et al. (2012) & + & + & + & + & + \\
\hline Gimenes et al. (2015) & + & + & + & + & + \\
\hline Vanessa et al. (2015) & $?$ & + & + & + & + \\
\hline Yazid et al. (2015) & + & + & + & + & + \\
\hline Ferreira et al. (1997) & + & + & + & + & + \\
\hline $\mathrm{Ng}$ et al. (2011) & + & + & + & + & + \\
\hline
\end{tabular}


TABLE 4. Risk of bias ratings for in vitro studies

\begin{tabular}{|c|c|c|c|c|c|}
\hline Risk of bias/ Author & $\begin{array}{l}\text { Selection } \\
\text { bias }\end{array}$ & Performance bias & $\begin{array}{l}\text { Exclusion } \\
\text { bias }\end{array}$ & $\begin{array}{l}\text { Detection } \\
\text { bias }\end{array}$ & $\begin{array}{c}\text { Reporting } \\
\text { bias }\end{array}$ \\
\hline Rodrigo et al. (2004) & + & + & $?$ & - & + \\
\hline Rhee et al. (2000) & + & + & + & + & + \\
\hline Ferlazzo et al. (2003) & + & + & + & + & + \\
\hline $\begin{array}{l}\text { Monastyrskaya et al. } \\
\text { (2013) }\end{array}$ & + & + & + & + & + \\
\hline Rescher et al. (2006) & + & $?$ & + & - & + \\
\hline Prates et al. (2015) & + & + & + & + & + \\
\hline Lu et al. (2012) & + & + & + & + & + \\
\hline Ernst et al. (2004) & + & + & + & + & + \\
\hline Hirata et al. (1980) & + & + & $?$ & - & + \\
\hline $\begin{array}{l}\text { Probst-Cousin et al. } \\
(2002)\end{array}$ & + & + & + & - & + \\
\hline Vergnolle et al. (2004) & + & + & + & + & + \\
\hline Kosicka et al. (2013) & + & + & + & + & + \\
\hline Lin et al. (2008) & + & + & + & + & + \\
\hline Ferreira et al. (1997) & + & + & + & + & + \\
\hline
\end{tabular}

